\title{
Supply and Demand for Catalogers Present and Future
}

\section{Joan M. Leysen and Jeanne M. K. Boydston}

This paper presents results from a fall 2003 survey of heads of cataloging at Association of Research Libraries United States academic libraries. The survey focused on the current number of professional catalogers and their responsibilities as well as future projections for demand for catalogers and thoughts about their roles. The study found that the numbers of professional catalogers are remaining constant or decreasing, and approximately one-third are projected to retire in the next decade. In addition, the role of the professional cataloger is perceived as continuing to evolve toward more cataloging-related activities and management and less direct cataloging. Most respondents predicted the professional cataloger has a role in the future and felt prepared for that future. Some respondents suggested that metadata cataloging would be a growing role in that future. This paper concludes with additional questions about the future of professional catalogers and cataloging.

Tn the coming years, the number of catalogers is predicted to drop significantly 1 due to the aging and subsequent retirement of the cataloging workforce. Wilder reported that catalogers in Association of Research Libraries (ARL) constitute one of the oldest categories of an aging librarian population. ${ }^{1}$ He further speculated that "fully one-third of the 2000 ARL cataloging population will retire by 2010." At a 2003 American Library Association (ALA) Conference, Camden stated that "Over one half of Library of Congress [LC] catalogers are eligible for retirement; almost $80 \%$ of LC paraprofessionals are over 50 years of age."” Many library school students are also older and enter the profession as second careers or after working in libraries as paraprofessionals. Library school faculty are also aging. ${ }^{4}$ As these catalogers, cataloging educators, trainers, and supervisors retire in the coming years, the profession will lose a wealth of knowledge and experience.

New cataloging hires have not been keeping pace with those leaving the profession. Beile and Adams reported a decrease of more than 10 percent in the number of cataloging positions advertised from 1988 to $1996 .{ }^{5}$ Even more dramatic is Wilder's comparison of cataloging hires with those of functional specialists. Wilder defined these functional specialists as professionals without MLS degrees working in areas such as systems analysis, personnel, and archives. He reported that the hiring of functional specialists increased 523 percent between 1983 and 2000, compared to a 46 percent decrease in cataloger new hires. ${ }^{6}$ Fewer new recruits are entering the workforce to become trained catalogers equipped with the skills and knowledge needed to replenish those catalogers who will be exiting the profession in coming years.

A reduction in the number of job prospects directly affects the student enrollment in professional cataloging and technical services programs. Library
Joan M. Leysen (jleysen@iastate.edu) is the Social Sciences Monographs Cataloger and Electronic Resources (jboydsto@iastate.edu) is the Humanities Monographs Cataloger and Serials Cataloger, lowa State University Library, Ames.

Acknowledgment: The authors wish to thank Christine Avery, Head, Commonwealth College Libraries, University Park, Pennsylvania, for her assistance with this paper. 
schools have reduced the number and level of courses in cataloging or eliminated cataloging as a required course for all students. Hill wrote, "By the mid 1980s, most library schools offered at most two cataloging courses, and the first was increasingly not a cataloging course per se, but was instead a kind of 'cataloging appreciation course."'7 Joudrey's more recent study of the cataloging curricula at 48 library science schools reported that the "percentage of programs that require a basic cataloging course has declined from $63 \%$ to $43.8 \%$ " when compared to a similar 1997 study by Vellucci. ${ }^{8}$ Likewise, Hsieh-Yee observed, "Cataloging education has indeed been reduced. There is a pattern of providing general coverage of cataloging in a required introductory course such as information organization or knowledge organization instead of offering a cataloging course."

Low salaries and poor image also may influence those considering a cataloging career. Cataloging and catalogers have received a negative image both in library school programs and within the academic library. In addition, as with many traditionally female-dominated professions, increased career opportunities with higher financial compensation have lured away many potential librarians. ${ }^{10}$

This drop in the numbers of professional catalogers is especially significant in the last decade as the emergence of new formats, such as Internet resources, DVDs, and other digitized content, add to an already full cataloging workload. Multiple formats, aggregations of content, and emerging metadata schemes present new challenges to those catalogers who provide access to these materials. In addition, some libraries (in Michigan, Colorado, and Kansas) have been collaborating with other organizations to provide access to digital collections and are involving catalogers in this process. ${ }^{11}$ Projects such as these illustrate a changing role for catalogers. Opportunities for collaboration with individuals outside technical services and the library could offer catalogers of the future a more visible presence in the university community.

However, a contradiction seems to exist between the need for cataloger's skills in accessing new formats and the diminishing supply and value placed upon professional catalogers. As early as 1992 Rodriguez commented, "The paradox of cataloging today is the growing importance of cataloging and the declining importance of catalogers." ${ }^{2}$ The question then arises of how libraries are coping with this situation.

The purpose of the present study is to examine in more detail some issues surrounding the supply and demand for professional catalogers. Is there a shortage of professional catalogers? If so, what is its extent? Is there a reduced need for professional catalogers and their skills, or have those needs changed? Are libraries prepared for these changes, and what are they doing about it? Answers to these questions are crucial in providing an honest appraisal of the future for those interested in cataloging as a profession and to those currently employed as catalogers. These findings also will provide support to educators who are advising and guiding these professional careers. In this paper, a professional cataloger is defined as one whose position requires a Master of Library Science (MLS) or equivalent library degree. A paraprofessional cataloger is defined as one whose position does not require a MLS. The professional cataloger is the primary focus of this paper.

\section{Background and Review of the Literature}

Over the last several decades, cataloger shortages have been reported and described in the literature and at conferences. Technological advances, the uncertain economy, reduced hiring, and a declining emphasis on cataloging in library school curriculums have contributed to the thinning of the cataloger ranks. Bishoff's summary of the supply and demand of catalogers from the mid-1960s to mid-1980s illustrates how technological advances have both reduced the need for the professional catalogers as well as increased the value of cataloging skills and knowledge. ${ }^{13}$ Catalogers, like other library employees, were plentiful in the 1960s, with federal financial support for higher education and library programs. Library staff were being hired in response to an expanding baby boomer generation entering higher education. The introduction of the MARC format in the 1960s and, especially, the emergence of bibliographic utilities in the 1970s were the beginnings of technological advances that have continued to affect the position of the professional cataloger. Shared databases of cataloging records, such as that of OCLC, resulted in more available cataloging copy that, in turn, allowed for greater flexibility in cataloging staffing and improved efficiency. Much of the cataloging traditionally assigned to the professional was shifted to paraprofessionals, a trend that continues today. ${ }^{14}$ Mohr and Schuneman reported that, by 1995, paraprofessional catalogers were performing some form of original cataloging, traditionally the responsibility of professionals, in 77.1 percent of ARL member libraries. ${ }^{15}$ El-Sherbini and Klim added, "professional catalogers are being assigned the responsibility for education and training of staff, quality control of the product, and management of the new workflow."16

Reports of a diminishing pool and lower quality of applicants started to appear in the late 1970s. Hill theorized that more opportunities were available for women in other fields and that many were choosing those instead of librarianship. Special and corporate librarianship were also more appealing to library school graduates. Hill attributed some of the responsibility for the decline in new recruits to library schools' portrayal of cataloging as "a dry, picky, mechanical, menial process involving the exercise of neither thought nor 
imagination; and that cataloging has nothing to do with service." ${ }^{.17}$ In June 1986, the ALA Cataloging and Classification Section Task Force on Education and Recruitment for Cataloging issued a report underscoring the difficulties in cataloger recruitment. ${ }^{18}$

At the same time, others were forecasting the demise and deprofessionalization of cataloging. Harris observed that deprofessionalization was occurring as cataloging was losing control of its knowledge base. She attributed this deprofessionalization to cataloging's female-dominated workforce with low-level positions, automation, and the growing involvement of the private sector in information work. ${ }^{19}$ Interviewing catalogers at five libraries, Hafter reported catalogers felt "that their status in their specific institutions, and in the library profession in general, was in a process of drastic decline. ${ }^{\prime 20}$ She also found that catalogers were concerned about the diminishing quality of cataloging records being produced and the types of materials left for professionals to catalog. Lack of clearly defined roles has added to confusion in how catalogers are viewed by themselves and others. The blurring of the roles between professional and paraprofessional catalogers has contributed to the appearance that technical services is largely a clerical function. ${ }^{21}$ Paraprofessionals also can feel resentment when their roles are not clearly defined and when they lack understanding of why their roles are changing. ${ }^{22}$ The institutional culture also may affect the acceptance of role changes. ${ }^{23}$

"Is Technical Services Being Deprofessionalized?" was the topic of the 1998 Association for Library Collections \& Technical Services (ALCTS) Role of the Professional in Academic Technical Services Discussion Group Meeting. At that session, Hamilton commented that deprofessionalization had occurred, but "that we, as a profession, are simply in denial about it." ${ }^{\prime 24}$ She questioned whether the patron had benefited from this deprofessionalization. Gillham postulated that the movement of tasks from professional to paraprofessional is not deprofessionalization. In her view, deprofessionalization occurs when there is a shifting of standards. ${ }^{25}$

In the later 1980s, Intner observed a reprofessionalization of catalogers as online catalogs appeared and libraries were seeking catalogers who could assist with retrospective conversion and online public access catalog (OPAC) implementations:

Colleges and universities that had shifted professionals away from cataloging began to think of ways to woo them back, but this time, the idea was that they would manage the libraries' bigger, better computerized bibliographic systems. The old original cataloger became a database manager, a systems design specialist, or a bibliographic control librarian. ${ }^{26}$
OPAC vendors also were recruiting catalogers "for system design and analysis, user support, product development, sales and project management. ${ }^{\prime 27}$ Yet by 1989 , the shortages were still reported as practitioners and educators gathered at a Simmons College Symposium to develop strategies for improved recruitment and education. ${ }^{28}$ Even though the profession has made strides to improve recruitment and education for professional catalogers, little documentation in the literature shows that these periods of shortages have been followed by any measurable increase in the hiring of catalogers.

As more paraprofessionals assumed duties formerly performed by professionals, fewer professional catalogers were being hired, and the responsibilities of the working professional cataloger continued to change. Studies of cataloging job advertisements provide one method for tracking the changing role of catalogers. These investigations vary in the sample size, positions reviewed, time period studied, requirements examined, and source of the job advertisement. Most of the research has been limited to postings in print journals. Examining job advertisements has its limitations in defining the nature of the work. Requirements may be broader than the position in order to attract a larger applicant pool, and they do not provide the qualifications of the individual actually hired for the position. However, these studies can provide some insight into cataloger role changes. Although computer skills continued to be focused on knowledge of and experience with bibliographic utilities and automated library systems, microcomputer applications appeared to be slowly increasing as a requirement between 1974 and 1994. ${ }^{29}$ Experience and knowledge of metadata schemes and tools were also appearing in position descriptions. ${ }^{30}$ Comparing cataloger and reference librarian job requirements and qualifications from 1971 through 1990, Xu reported that while both positions required computer skills, each required skills unique to their respective positions. ${ }^{31}$ In a 1988 study, Reser and Schuneman reported technical services position advertisements were more likely to require computer skills, foreign language skills, and previous work experience than public services positions. ${ }^{32}$ Replicating the Reser and Schuneman methodology in 1996, Beile and Adams concurred that foreign language skills were more often required for technical services positions, but they refuted the early findings regarding computer skills and previous work experience. ${ }^{33}$ Chaudhry and Komathi reported that "knowledge of cataloguing tools and resources" and "knowledge of automated cataloguing systems" were the top two requirements appearing most often in cataloging job advertisements in the 1990s and these requirements increased in the latter half of the decade. ${ }^{34}$ This article also supports the view that traditional cataloging skills are still desired even in the electronic environment. By 2002, job advertisements for cataloging positions showed more significant changes than in the previous three decades. Electronic resources specialist and metadata special- 
ist positions began to appear, and requirements included skills and knowledge in such standards as Dublin Core, Hypertext Markup Language (HTML), eXtensible Markup Language (XML) as well as project management experience. ${ }^{35}$ Hosoi found that special format cataloging was the most frequently mentioned required or preferred qualification in addition to traditional skills. $^{36}$

Similar changes in cataloging positions are evident in studies using survey methodology. Buttlar and Garcha studied the responsibilities of catalogers over a ten-year period from 1987 through 1997. Their findings showed that cataloging members of ALCTS were still involved in descriptive cataloging, subject analysis, and classification in more than 90 percent of the libraries surveyed in 1997. ${ }^{37}$ However, since 1987, these members have expanded their cataloging to include audiovisual materials, digital documents, and Internet resources. ${ }^{38}$ Participants also commented that education and training in computer technology skills is not keeping pace with the expectations that catalogers have these skills. ${ }^{39}$ A 2003 survey of cataloging practitioners revealed that the staff "defining and/or applying metadata standards" were most often catalogers, and 79 percent of the practitioners surveyed indicated that cataloging librarians or staff were involved in digital projects, especially in a consulting role or in "determining metadata standards or elements."

The ALCTS Role of the Professional in Academic Technical Services Libraries Discussion Group, created in 1977, continues to be a forum for discussions and concerns surrounding the changing role of the professional cataloger. In the last several years this group has discussed a range of topics that included library school education, the changing technical services environment brought about by budget constraints and staffing concerns, technical services' role in developing and interpreting new services, and the transition between retiring and new technical services professionals. Based on experiences at Texas A \& M University in Commerce, Akins recommended that this transition avoid practices such as job shadowing, which relies heavily on the person retiring. ${ }^{41}$ She also reported that good documentation on the roles of professional and paraprofessional would assist with the smooth transition.

Proactive involvement of catalogers in new digital projects was another topic of this ALCTS discussion group's meeting. Gerhart mentioned that catalogers at the University of Washington Libraries were members of various committees that provided metadata knowledge and documentation to other library staff and served as consultants to the library and university on metadata projects. ${ }^{42}$ Pennell also spoke about North Carolina State University's technical services librarians' expertise and skills that were pertinent to their involvement in the digital environment. ${ }^{43}$ The ability to see the big picture, leadership and coordinating skills, and knowing emerging metadata standards were some other skills desired for catalogers in the new environment. ${ }^{44}$

Many directors of large research libraries have reported being in the initial phases of digital initiatives due to the slow pace of developments in standards, workflows, policies, and procedures. Yet other institutions like Cornell University are marketing their digital services to areas outside the library. ${ }^{45}$

With the rapid growth of the Internet in the 1990s, articles started to showcase cataloging skills and their relevance in providing organization to electronic information. ${ }^{46}$ Horney summarizes these views, "One of the most positive aspects of cataloging today is recognition of the importance of expertise in organizing and describing non-book materials. Catalogers that have this expertise are particularly well positioned to meet future challenges as Internet resources become more crucial to library service. ${ }^{27}$ Following the discussions of the Library of Congress Bicentennial Conference on Bibliographic Control for the New Millennium held in 2000, articles on the development of metadata standards and their application in providing access to future resources have appeared. Some of these articles mention the role of catalogers in organizing electronic information. ${ }^{48}$ Commenting on the skills for digital catalogers, St. Clair denotes, "Catalogers' traditional strengths - their organization of information, their understanding about the inherent relationships among disciplines, and their focus on issues of retrieval" are seen as valuable for the future. ${ }^{49}$ Yet others express concern about the lack of cataloger training and experience in this new area of metadata and digital resources. ${ }^{50}$ As these opportunities continue to grow, will trained catalogers participate in these projects, or will catalogers be excluded because they lack training or the supply of catalogers is just not available?

\section{Method}

To provide a more in-depth analysis of cataloger supply and demand issues and the impact of these issues on ARL libraries, the authors developed a survey instrument, which is presented in the appendix. It concentrated primarily on those catalogers whose position required an MLS, although some survey questions addressed the paraprofessional cataloger. The survey covered four broad areas: the number (increase or decrease) of professional catalogers, the time (increase or decrease) these catalogers spend on cataloging and other activities, recruitment of the professional cataloger, and opinions on the future for catalogers and cataloging. The survey contained 57 questions, many of which required a yes or no response; other questions, however, offered an opportunity for open-ended comments and opinions. The authors intentionally designed the survey to be fairly short to facilitate a 
higher return rate. They conducted an informal pretest of the survey instrument among a small sample population. Additionally, selected library colleagues proofread the survey for clarity. Based on their feedback, the survey instrument was revised. ARL academic libraries located in the United States formed the population sample for this study. While large enough to provide a representative sample, the limited number of libraries (100) also facilitated the timely analysis of the data. Additionally, data from prior studies of these libraries was used to make comparisons.

In October 2003, the survey was mailed to the heads of technical services departments, or the equivalent position, at these ARL libraries. A cover letter outlined the survey purpose, provided instructions for completing it, and assured participants that data would be reported in the aggregate. Respondents could return the finished survey by mail or fax. After the initial deadline for completion, an e-mail reminder was sent. Once the surveys were returned, the results were coded and analyzed.

\section{Findings}

Responses came from all geographic regions in the United States, and the percentage of responses from public and private institutions mirrors the distribution found within ARL as a whole; see table 1 . This table also shows the total number of professional and paraprofessional catalogers in the responding libraries. In addition to professional and paraprofessional catalogers, 42 percent of the respondents have library science practicum students or interns performing cataloging. Approximately one-third of the libraries hired paraprofessional catalogers specifically for their subject or language expertise. Not every respondent answered all the survey questions. When this occurred, numbers of respondents are provided in parentheses following percentages.

To determine if the numbers of catalogers might be affected by future retirements, the survey asked libraries to estimate the number of professional and paraprofessional catalogers aged fifty or older. These numbers ranged from 0 to 10 full-time equivalent (FTE) professional catalogers and 0 to 11 FTE paraprofessionals per library. Viewed in another way, an average 36 percent (423) of the catalogers working in these ARL libraries are in positions that require an MLS, and 38 percent of them are older than fifty. Paraprofessional catalogers make up 64 percent (766) of the cataloging population in these libraries, and 32 percent of them are age fifty or older.

\section{Numbers of Catalogers}

The next section of the survey focused on whether the numbers of catalogers had changed since 1998. Fifty-five percent (33) of the respondents reported a decrease in the number of FTE professional catalogers. Reasons for the decrease appear in table 2.

A position or funding reallocation to other areas of the library and cataloger retirements or resignations were the most frequent reasons for this decrease. Less need for professional cataloging skills and fewer qualified applicants were mentioned as secondary factors. Seventeen percent (10) of the respondents reported an increase in the number of professional catalogers. The most noted reason for this increase was the need for catalogers with knowledge of special languages, subjects, or formats (see table 3).

Table 1. Demographics

\begin{tabular}{lcc}
\hline & \multicolumn{2}{c}{ ARL libraries responding } \\
& No. & $\%$ \\
Public & 42 & 70 \\
Private & 18 & 30 \\
Total & 60 & 100 \\
& \multicolumn{2}{c}{ No. of catalogers } \\
& No. & $\%$ \\
MLS required & 423 & 36 \\
Paraprofessionals & 766 & 64 \\
Total & 1189 & 100 \\
& & \\
\hline
\end{tabular}

Table 2. Factors involved in the decrease in the number of professional catalogers

\begin{tabular}{|c|c|c|c|c|}
\hline Factors & $\begin{array}{c}\text { Yes } \\
\text { No. \% }\end{array}$ & $\begin{array}{l}\text { No } \\
\text { No. } \%\end{array}$ & $\begin{array}{l}\text { Don't k } \\
\text { No. }\end{array}$ & now \\
\hline Retirements or resignations $(\mathrm{N}=32)$ & 2372 & 825 & 1 & 3 \\
\hline $\begin{array}{l}\text { Less need for professional } \\
\text { skills }(\mathrm{N}=31)\end{array}$ & 826 & 2374 & 0 & 0 \\
\hline $\begin{array}{l}\text { Position or funding reallocated } \\
\text { to other areas of library }(\mathrm{N}=33)\end{array}$ & 2679 & 618 & 1 & 3 \\
\hline $\begin{array}{l}\text { Fewer qualified applicants to fill } \\
\text { vacant positions }(\mathrm{N}=31)\end{array}$ & 413 & 2684 & 1 & 3 \\
\hline
\end{tabular}

Some totals do not equal 100 percent due to rounding.

Table 3. Factors involved in the increase in the number of professional catalogers

\begin{tabular}{lccccc}
\hline Factors & $\begin{array}{c}\text { Yes } \\
\text { No. } \%\end{array}$ & $\begin{array}{c}\text { No } \\
\text { No. \% }\end{array}$ & $\begin{array}{c}\text { Don't know } \\
\text { No. \% }\end{array}$ \\
$\begin{array}{l}\text { Knowledge of special languages, } \\
\text { subjects or formats }(\mathrm{N}=10)\end{array}$ & 880 & 1 & 10 & 110 \\
$\begin{array}{l}\text { More advanced knowledge of } \\
\text { technological innovations (N=9) }\end{array}$ & 778 & 1 & 11 & 11 & 11 \\
$\begin{array}{l}\text { Supervisory/leadership skills/ } \\
\text { roles (N=9) }\end{array}$ & 667 & 333 & 0 & 0 \\
$\begin{array}{l}\text { Trainers needed (N=9) } \\
\text { Special projects (N=9) }\end{array}$ & 778 & 222 & 0 & 0 \\
& 222 & 778 & 0 & 0 \\
\hline
\end{tabular}


In 28 percent (17) of the libraries, the numbers of catalogers remained the same.

When asked if their library currently had professional cataloger vacancies, 66 percent (37) indicated "no," while 34 percent (19) answered "yes." The library budget did not prevent these vacancies from being advertised.

\section{Recruitment}

Respondents also replied to questions about recruitment practice at their institution. Almost half of the respondents indicated that they had hired a professional cataloger in the last two to four years. Forty-two percent hired a cataloger within the last year. Only 12 percent hired their last cataloger five or more years ago.

Since 1998, 52 percent of the respondents reported problems in recruiting professional catalogers. Slightly fewer than half reported no such problems. Three percent responded "not applicable" to this question. Respondents were provided with four possible reasons why libraries might have difficulty recruiting professional catalogers (see table 4). Lack of qualified applicants was cited as the primary source of this difficulty (97 percent). Almost half (49 percent) of the respondents also felt that the lack of a competitive salary was a factor. Forty-one percent of respondents felt the institution's location influenced recruiting, but an equal percent felt it did not. Half of the respondents that reported difficulty in recruiting indicated that their institution's criteria for tenure or continuing appointment was not an issue, while 36 percent said it was a factor. The local cost of living also was mentioned as a cause for concern.

\section{Time Spent Cataloging and the Cataloger's Role}

Not only have the numbers of professional catalogers decreased in many of the libraries surveyed, the amount of time the catalogers spend on cataloging also has decreased in 55 percent of the libraries. The time spent on cataloging increased in only 13 percent of the libraries and stayed the same in 32 percent.

Table 4. Factors in recruitment difficulties for professional catalogers

\begin{tabular}{lcccccc}
\hline Factors & \multicolumn{2}{c}{ Yes } & \multicolumn{2}{c}{ No } & \multicolumn{2}{c}{$\begin{array}{c}\text { Don't know } \\
\text { No. } \%\end{array}$} \\
$\begin{array}{l}\text { Lack of qualified } \\
\text { applicants }(N=30)\end{array}$ & 29 & 97 & 1 & 3 & 0 & 0 \\
$\begin{array}{l}\text { Criteria for tenure or } \\
\text { continuing appointment }(N=28)\end{array}$ & 10 & 36 & 14 & 50 & 4 & 14 \\
$\begin{array}{l}\text { Desirability of the community } \\
\text { or institution's location }(N=29)\end{array}$ & 12 & 41 & 12 & 41 & 5 & 17 \\
$\begin{array}{l}\text { Lack of competitive } \\
\text { salary }(\mathrm{N}=31)\end{array}$ & 15 & 49 & 10 & 32 & 6 & 19 \\
\hline
\end{tabular}

Some totals do not equal 100 percent due to rounding.
Respondents were presented with six possible reasons for the decrease in time spent on cataloging (see table 5). The two top reasons contributing to this decrease were catalogers spending more time on cataloging-related projects (such as systems integration and vendor product implementation) and on library service activities. More than 75 percent of the 33 respondents reporting a decrease also indicated professional catalogers spent more time on managerial and supervisory responsibilities and providing training. Additionally, paraprofessionals performed more cataloging, a reason given by 76 percent of the respondents. This further decreased the amount of cataloging performed by professionals. Eight respondents indicated the time professional catalogers spent in cataloging had increased. They attributed this increase to priority changes by administrators, desirability for improved access, and more items to catalog.

\section{Vendors and Outsourcing}

Almost all of the respondents (58) replied that they use vendor products or outsource cataloging, and 45 percent use these services "often" as an alternative to in-house cataloging. In 35 percent of the libraries, the decision to use these alternatives is based on "fewer catalogers to do the work" and "library budgetary issues." Fifty percent of the respondents provided additional reasons for using these services. Improved efficiency-by allowing professional catalogers time to focus on more difficult, specialized cataloging or more challenging work-and the need to eliminate backlogs were also mentioned.

\section{Future}

In the last section of the survey, respondents were given a series of scenarios regarding the possible future of profes-

\begin{tabular}{lcccccc}
\multicolumn{2}{l}{ Table 5. Professional cataloging time decreased } \\
\hline Reasons for decreased time & \multicolumn{2}{c}{$\begin{array}{c}\text { Yes } \\
\text { No. } \%\end{array}$} & $\begin{array}{c}\text { No. } \\
\text { No. }\end{array}$ & $\begin{array}{c}\text { Don't know } \\
\text { No. } \%\end{array}$ \\
$\begin{array}{l}\text { More cataloging by } \\
\text { paraprofessionals }(N=33)\end{array}$ & 25 & 76 & 8 & 24 & 0 & 0 \\
$\begin{array}{l}\text { Professional catalogers } \\
\text { needed for training }(N=31)\end{array}$ & 24 & 77 & 6 & 19 & 1 & 3 \\
$\begin{array}{l}\text { More time spent on library } \\
\text { service/library committees }(N=32)\end{array}$ & 27 & 84 & 5 & 16 & 0 & 0 \\
$\begin{array}{l}\text { More time spent on tenure or } \\
\text { continuing appointment } \\
\text { requirements }(N=32)\end{array}$ & 17 & 53 & 14 & 44 & 1 & 3 \\
$\begin{array}{l}\text { More time spent on managerial/ } \\
\text { supervisory responsibilities }(N=33)\end{array}$ & 26 & 79 & 7 & 21 & 0 & 0 \\
$\begin{array}{l}\text { More time spent on related activites } \\
\text { (systems integration, etc.) }(N=33)\end{array}$ & 29 & 88 & 4 & 12 & 0 & 0
\end{tabular}

Some totals do not equal 100 percent due to rounding. 
sional catalogers and their changing role in the profession (see table 6). Respondents were asked to rate each statement on a four-point scale ranging from "strongly disagree" to "strongly agree." They also had an option for "no opinion."

Most respondents "agreed" or "strongly agreed" that libraries will continue to recruit for beginning-level professional cataloging positions (53 percent and 19 percent respectively), but that the responsibilities of these catalogers will shift from cataloging to more training and administrative tasks. In addition, 53 percent "agreed" and 8 percent "strongly agreed" that libraries would hire graduates with subject or language degrees and train them as catalogers. The survey did not address the reasons why libraries might take this action. Outsourcing also will play a strong part in the future of cataloging, with 47 percent of the respondents "agreeing" and 30 percent "strongly agreeing" that libraries of the future will outsource more materials to be cataloged.

Considering the present and future shortages of catalogers, recruitment difficulties, and changing cataloger roles, the survey asked participants how well their library was prepared for the future. Most respondents felt they were "prepared" (63 percent) or "very prepared" (14 percent) for the future. Only 19 percent felt "unprepared" or "very unprepared" ( 2 percent), and 3 percent indicated "no opinion." Many respondents provided written comments on the future state of cataloging and catalogers. They indicated that flexibility on the part of professional catalogers to try new approaches, willingness to adapt to new technologies, and administrative support for cataloging are three important factors in future planning for cataloging. Many reported analyzing relevant staffing and workflows and developing strategies for moving traditional cataloging activities to other staff. Others mentioned outsourcing some materials so professional catalogers can become involved with new initiatives. In addition, respondents mentioned an emphasis on staff development and training in the area of technological innovations, simplifying cataloging procedures, and mentoring between professional and paraprofessional catalogers as signs of preparedness for the future. Several also referred to partnering and collaboration between catalogers and other library staff on such projects as metadata creation. Respondents who felt their library was unprepared for the future expressed concerns about losing the expertise and skills of their experienced catalogers to retirement and concerns that the library administration had no plans to replace that experience. Others mentioned the need for cataloger training, especially in standards that go beyond the MARC format; lack of planning and involvement of staff in planning for the future; and a need for more longterm solutions.

Being proactive in promoting cataloging knowledge and skills was important. Forty-two percent (57) of the respondents indicated that their library made an effort to showcase and explain the knowledge, skills, and roles of professional catalogers to other areas of the library and university community, but 58 percent (57) indicated their library had not done so. Several libraries showcased cataloging skills and knowledge by communicating cataloging policies, achievements, and projects to the library community. They achieved this communication through in-house staff training, PowerPoint presentations, open houses, and information on the department's Web page. These libraries also encouraged catalogers to be involved in the library's mission and objectives by participating in the intellectual life of the library through active membership in major or innovative committees. This increases the visibility of catalogers and communicates the relevance of their skills to library activities. Several respondents commented on the value of cataloger involvement in digital projects and metadata services.

If catalogers are to be involved in such new initiatives as metadata, continuing education and training will be essential. Fifty-eight percent (57) of the respondents felt their libraries "strongly encouraged" the continuing education and training of professional catalogers, 32 percent gave a "medium level of encouragement," and 10 percent

Table 6. Future state of professional catalogers and cataloging

\begin{tabular}{|c|c|c|c|c|c|c|c|c|c|}
\hline Future & $\begin{array}{r}\text { Stron } \\
\text { disag } \\
\text { No. }\end{array}$ & $\begin{array}{c}\text { gly } \\
\text { ree } \\
\%\end{array}$ & $\begin{array}{l}\text { Disa } \\
\text { No. }\end{array}$ & $\begin{array}{l}\text { gree } \\
\%\end{array}$ & $\begin{array}{l}\text { Agree } \\
\text { No. } \%\end{array}$ & $\begin{array}{r}\text { Stro } \\
\text { ag } \\
\text { No }\end{array}$ & $\begin{array}{l}\text { igly } \\
\text { ee } \\
\%\end{array}$ & $\begin{array}{l}\text { No } \\
\text { opin } \\
\text { No. }\end{array}$ & $\begin{array}{l}0 \\
\text { ion } \\
\%\end{array}$ \\
\hline Libraries will recruit beginning-level professional catalogers $(N=59)$ & 5 & 9 & 8 & 14 & 3153 & 11 & 19 & 4 & 7 \\
\hline $\begin{array}{l}\text { Professional responsibilities will shift from cataloging } \\
\text { to adminstration/management }(N=59)\end{array}$ & 2 & 3 & 12 & 20 & $27 \quad 46$ & 16 & 27 & 2 & 3 \\
\hline Professional responsibilities will shift from cataloging to training $(N=59)$ & 0 & 0 & 7 & 12 & 3864 & 7 & 12 & 7 & 12 \\
\hline $\begin{array}{l}\text { Graduates with subject/language degrees will be hired/trained } \\
\text { in cataloging }(N=59)\end{array}$ & 5 & 8 & 14 & 24 & $31 \quad 53$ & 5 & 8 & 4 & 7 \\
\hline Libraries will rely more on outsourcing cataloging $(N=60)$ & 1 & 2 & 9 & 15 & $28 \quad 47$ & 18 & 30 & 4 & 7 \\
\hline
\end{tabular}


offered "little" or "no encouragement." As a final question, respondents were asked whether they would recommend someone obtain an MLS degree with a focus in cataloging. An overwhelming 93 percent replied "yes."

\section{Discussion}

The number of catalogers in ARL libraries varies from institution to institution. The institution and collection size, centralized versus decentralized cataloging, uniqueness of the collection, proximity to a library school, and budgetary conditions are variables that may affect the number of catalogers at any given time. One common pattern that emerges among these academic libraries is that paraprofessional catalogers outnumber professional catalogers almost two to one. Eskoz reported a similar finding in a 1986-1987 study of 40 academic libraries in universities with enrollments of 20,000 or more. ${ }^{51}$ This division of staffing has been maintained despite further technological advancements. The numbers of professional catalogers are decreasing or staying the same in the majority of these ARL libraries. The decline in numbers is attributed to retirements or resignations and position or funding reallocation to other areas of the library. Although age is only one factor in predicting future retirements, one can expect that approximately one-third of the ARL catalogers represented in this study could retire in the next decade. This finding is similar to Wilder's demographic predictions for future retirements mentioned earlier in this paper. ${ }^{52}$ The reduction in the number of professional catalogers also may be due to more cataloging being transferred to paraprofessionals, but no evidence in response to this survey supports this conclusion. However, most respondents did not attribute the decrease in professional catalogers to less need for cataloging skills. Libraries are still valuing cataloger skills but perhaps are training paraprofessionals in these skills instead of employing additional professional catalogers. This may explain why the numbers of professional catalogers stayed the same at some libraries. Other reasons may be that some libraries have fewer vacancies, greater success in filling vacancies, or little staff turnover. Internal reorganization and reclassification of staff also may account for the fixed numbers of cataloging staff. This stability in numbers also may indicate a shift in cataloger responsibilities such as that described by Ouderkirk:

Cataloging tasks have traditionally moved along a continuum. In the innovation phase, new processing techniques are usually pegged at pro- fessional level. When those techniques have become routine and the next innovation has appeared, the same procedures become paraprofessional tasks. ${ }^{53}$

Only 8 respondents reported an increase in the number of professional catalogers. The reasons for this increase included the need for catalogers with special skills and knowledge of languages, formats, or subjects; advanced knowledge of technological innovations; and training and supervisory skills. No evidence, however, suggests that this increase will continue in the future.

Libraries have little control over economic conditions that affect supply and demand of staffing. Administrators are forced to make difficult decisions as they struggle to meet expanding user expectations for the latest and fastest developments in information retrieval with fewer dollars. The work performed by catalogers is largely invisible to the public; therefore, it is more susceptible to budget cuts and often can result in vacant positions or reallocations to public services areas of the library. Wells stated:

The availability of outsourcing options may also cause administrators to look first at cataloging, with its traditionally higher percentage of librarians than in other technical services areas, when considering reductions of professional and support staff in times of financial difficulty. ${ }^{54}$

Wells' survey of 11 Southeastern academic libraries provides recent evidence of the effect of budget cuts on lost technical services positions. She reported that 62.8 percent of the libraries she surveyed had lost technical services positions due to budget reductions since $1990 .{ }^{55}$ The librarian ranks were especially affected by these budget constraints. Paraprofessional positions also were lost by more than half of the respondents. ${ }^{56}$ In almost half of the libraries, these lost positions were not reinstated. ${ }^{57}$ The most affected area within technical services was cataloging. ${ }^{58}$ "Seventy-five percent of the libraries that had lost positions reported they had reorganized their technical services operation. ${ }^{.59}$ Other means of dealing with the lost positions included transferring work of librarians to other staff (52.3 percent) and outsourcing (25 percent). ${ }^{60}$

Respondents in this study gave many reasons for recruitment failures, mirroring those of earlier studies. Lack of qualified applicants and less than competitive salary were mentioned as being the most significant reasons for failed searches. A 1986 ALCTS task force reported that the poor quality of the applicant pool, lack of clearly stated relevant experience, and low salary were responsible for recruitment failures. ${ }^{61}$ While these studies concentrate on recruitment for catalogers, such issues are not unique to cataloging posi- 
tions. Members of the Human Resources Section of ALA's Library Administration and Management Association division reported that the "lack of MLIS degree holders and low salaries at their institutions" were the top two reasons for recruiting difficulties. ${ }^{62}$

Commenting on the decrease in cataloger hiring, Wilder observed:

the extent of the drop, its consistency over an extended period of time, and across a large number of large academic libraries, makes unavoidable the conclusion that a fundamental shift has occurred in the staffing priorities of academic libraries away from professional technical services/cataloging positions. ${ }^{63}$

The authors' survey data did not provide the evidence needed to determine whether this decrease in hiring is continuing. Most of the libraries surveyed had hired catalogers in the last five years, but the survey data provided no specifics about these hires. Whether the hiring was into a beginning- or experienced-level position, a position requiring unique skills, a temporary position, or an administrative assignment is unknown. How many times the position was advertised before being successfully filled or whether the search failed were aspects not covered in this survey. These topics merit further research.

Respondents in the current survey also foresee that their libraries will continue to recruit for beginning professional cataloging positions. Where these new recruits will come from is unclear. Cataloging faculty in library schools are aging and can be expected to retire in the next decade. As faculty retire, many times adjunct faculty replace them. These practicing catalogers may have good credentials for teaching cataloging; however, as adjunct faculty, they are in a poor position to affect the curriculum of library science programs. Furthermore, the numbers of accredited library science programs offering a doctoral level degree with a specialization in cataloging are diminishing. ${ }^{64}$

If cataloging courses are not being taught or required in library schools or if cataloging is being assimilated with other forms of bibliographic control, libraries may not have a strong pool of applicants from which to hire a beginninglevel cataloger. Libraries also may have to compete for catalogers with nonlibrary employers, such as vendors. Carbo estimates "that 20 percent of the most recent Pitt library school MLS graduates work outside libraries. A number of other library school deans concur." ${ }^{25}$

Respondents also indicated that they would hire graduates with subject or language degrees and train them in cataloging skills and knowledge. This practice is already occurring in many libraries, where paraprofessional catalogers are hired for their subject or language expertise. One
Association for College and Research Libraries (ACRL) task force has acknowledged the need to hire non-MLS degreed professionals who can advance upward in the library organization ${ }^{66}$ For example, the Council on Library and Information Resources plans to sponsor a Postdoctoral Fellowship for Humanists in Libraries as an alternative to the MLS and to alleviate shortages of MLS librarians. ${ }^{67}$ The extent of these initiatives to recruit non-MLS employees for library positions may have significant implications for the future of MLS programs, library salaries, library organization structures, and promotion and tenure criteria at faculty status institutions. One cannot make assumptions about whether these positions will include future catalogers.

A reduction in the amount of time spent cataloging materials is a further indication that the role of the professional cataloger continues to be changing. In libraries where professional cataloging time has decreased, individuals are devoting their time to other catalogingrelated responsibilities, such as systems integration and vendor product implementation. This is consistent with the 1997 Buttlar and Garcha findings that "catalogers were involved in activities formerly in the domain of systems/ automation librarians."

Catalogers also are more involved in managerial and supervisory responsibilities, a finding similar to that of Buttlar and Garcha, and Eskoz. Buttlar and Garcha reported an increase of 11.6 percent in cataloger supervision of support staff, a 12.9 percent increase in coordinating the work of subordinates, and a 8.5 percent increase in evaluating cataloging personnel between 1987 and $1997 .{ }^{69}$ Eskoz reported catalogers had a major role (45 percent) or limited role (25 percent) in supervision. ${ }^{70}$ However, this finding is contrary to Furuta's report of a downward trend in the administrative responsibilities of catalogers from 1984 to $1989 .{ }^{71}$ While more cataloging is performed by paraprofessionals, professional catalogers are still needed to train these paraprofessionals. Buttlar and Garcha also reported involvement among professional catalogers in training copy catalogers, managing workflows, preparing cataloging documentation, and developing policy increased over a ten-year period. ${ }^{72}$ The professional catalogers also are participating in the library and university community through service on committees. This illustrates their involvement in broader issues and the contribution of their unique skills and knowledge to the library and university mission and goals.

In the current study, 8 respondents indicated that the time professional catalogers spent on cataloging increased. The small number of respondents makes drawing conclusions difficult. However, one might speculate on a correlation between the factors responsible for the increase. From the combined responses of "changed priorities of administration," "more materials lack established guidelines," and "an increase in the number of materials to catalog," one 
might theorize that these libraries may be embarking on cataloging new formats or initiatives. Data from catalogers themselves outlining the percentages of their time spent on various responsibilities would provide more concrete data from which to draw conclusions.

Most libraries have used vendor-based products and services and outsourcing to assist with cataloging operations. Increased efficiency and improved use of staff to catalog more difficult or other materials were mentioned as advantages in using these resources. In 1997, Libby and Caudle reported a smaller percentage of libraries participating in outsourcing. ${ }^{73}$ The size of the collection and the number of current receipts were factors that affected the decision to outsource. Improved vendor quality, enhanced services, economic conditions, and priority changes may explain the wider acceptance of these services than in the past. Buttlar and Garcha reported that in 73 libraries that used outsourcing, local cataloging production had improved in 32 of them, and further, that outsourcing had little impact on the elimination of catalogers' positions. ${ }^{74}$ However, concessions associated with outsourcing cataloging have been identified in the literature. Loss of control over the library's local catalog, diminishing supply of original cataloging records contributed to shared bibliographic databases, and quality control issues are frequently mentioned..$^{75}$

Echoing earlier findings, many respondents also predicted that future cataloger responsibilities will shift from cataloging to more administrative, management, and training tasks. ${ }^{76}$ Gatti reported on the rise of the Generation X (born 1966-1976) cataloger as supervisor. ${ }^{77}$ This trend, in part, is occurring due to the aging of the cataloger management workforce and to the reluctance of current catalogers to assume supervisory roles. Library school programs will need to include these management skills in their cataloging curriculum as opportunities to learn these skills may not be available in the workplace. As Grenci reported, "Technical services work, both professional and paraprofessional, has changed and on the job apprenticeships are no longer the norm." ${ }^{, 78}$

Despite projections of a reduced cataloging workforce and impending cataloger retirements, the majority of respondents felt their library was prepared for the future. A supportive administration was clearly an important factor in this preparation. Respondents who feel prepared for the future indicated that library colleagues appreciate their catalogers' skills, and the organization recognizes the unique contribution made by their catalogers. Negative attitudes toward cataloging are mentioned by respondents that feel unprepared for the future. Many are concerned about impending retirements and the library administration's lack of commitment to a smooth transition for replacements. Few respondents commented on retention efforts for existing staff.

A few respondents mentioned metadata, content-linking technologies, and collaboration with faculty and the university community in creating an institutional repository as future cataloging activities. Discussions initiated at the Library of Congress 2000 Bicentennial Conference on Bibliographic Control for the New Millennium sparked several reports on the education and training required for catalogers to play an active role in organizing and accessing electronic content. Two action items of the "Bibliographic Control of Web Resources: A Library of Congress Action Plan" relate specifically to the education and training of catalogers. ${ }^{79}$ In response to Action Item 5.3, an ALCTS task force issued a proposal for the continuing education of cataloging professionals. ${ }^{80}$ This proposal acknowledges that not all catalogers will be participating in high-level cataloging activities and offers three levels of training ranging from those skills necessary for all catalogers to those for catalogers involved in the development of digital library projects.

A second ALCTS task force was charged with improving and enhancing curricula in library and information science programs. The Task Force 5.1 proposal recommends that metadata topics be incorporated into cataloging education (a concept supported by cataloging educators), and that these topics should be taught to all students. The plan provides various levels of expertise based on the student's career objectives, with the first level being recommended for all LIS students. ${ }^{81}$ The "effect of digital initiatives on cataloging operations" was also a topic of the ALCTS Heads of Cataloging Departments Discussion Group 2003 Midwinter Meeting. ${ }^{82}$

Several obstacles may delay professional cataloger involvement in these new digital initiatives. Some metadata schemes that often conflict with traditional cataloging standards are being developed by organizations outside the library. Advances in technology, such as automated harvesting of information, also may limit the need and level of cataloger involvement in organizing digital content. Catalogers may not have the depth of subject expertise required for specialized metadata projects. In a survey of library schools, conducted from April through May 2002, Hsieh-Yee discovered that, while metadata concepts were discussed in cataloging classes, few in-depth offerings were provided. ${ }^{83}$ Several professional library associations, however, do sponsor metadata workshops throughout the country.

\section{Summary and Conclusion}

The findings of this survey provided a snapshot of the professional cataloger position in ARL libraries, but still leave many unanswered questions about the future of the professional cataloger. In the majority of libraries represented in the survey, the numbers of professional catalogers are either staying the same or decreasing. Recruiting for professional cataloging positions continues to be difficult. In addition, 
approximately one-third of professional catalogers are aged fifty or older and potentially could retire in the near future.

The role of the professional cataloger is moving away from its primary focus on cataloging toward including management of cataloging activities. The majority of libraries will continue to use vendor products and services, which may also effect cataloging staffing. Most of the respondents in the survey felt their library was prepared for the future, but what that future might be is unknown. Libraries will continue to recruit professional catalogers, but cataloger responsibilities may be different and include administrative roles. In addition, new positions focusing on skills needed to address technological advances will evolve. Important areas for further investigation include determining how functional specialists affect the future of the professional cataloger and examining appreciation of and need for cataloger skills in contrast to the appreciation of and need for the professional cataloger.

While participants in this study overwhelmingly endorsed the idea of future professionals specializing in cataloging, many factors could affect this future. Technological innovations and an aging cataloging workforce certainly will be two important factors. Will academic libraries expand their use of vendor services and products and continue to move professional cataloging work to paraprofessionals, or will libraries, library schools, and our professional organizations continue to support cataloging as a professional activity? How will library schools fit into this picture with closings and lessening emphasis on cataloging?

Discussions and reports have indicated a future need for cataloging skills, especially for the current and future electronic environment. Little is known of the depth or the duration of this need. For example, digitization projects may vary among institutions. The scope of the collection can determine whether the project will be of short duration or one that will continue over time. Partnering with other institutions may make decisions (such as selecting a metadata st andard and involvement of catalogers) more challenging. Technological advances may reduce the need for professional catalogers in these emerging projects; this is another area where further research is needed.

Academic libraries will need to address the questions raised by this study. If current trends continue, the professional cataloging workforce will not be able to replenish itself with new recruits. Thus, fewer professional catalogers will be available to provide necessary leadership and direction in meeting the challenges of rapid technological change and future information organization and retrieval needs. Fewer professionals will be applying their knowledge of information organization and retrieval to training others, managing workflows, and creating original bibliographic records to be shared among other libraries and users. In addition, the development and implementation of new standards and access methods will be dependent upon the skills and knowl- edge of a very limited number of catalogers. These standards are the foundation that has facilitated cooperative cataloging and fostered the application of new technologies.

The library profession and academic libraries must continue to define the role of professional cataloger. Better recognition of the value of cataloger's skills and contributions is needed now, as is a continuing dialogue between academic libraries and library schools. Only then can library schools further educate and supply catalogers capable of addressing the information organization and retrieval needs of the future.

\section{References}

1. Stanley J. Wilder, Demographic Change in Academic Librarianship (Washington, D.C.: Association of Research Libraries, 2003).

2. Stanley J. Wilder, "Demographic Trends Affecting Professional Technical Services Staffing in ARL Libraries," Cataloging d Classification Quarterly 34, no. 1/2 (2002): 53.

3. Brad Eden, "Report on the ALCTS Heads of Cataloging Discussion Group Meeting, American Library Association Annual Conference, Toronto, June 2003," Technical Services Quarterly 21, no. 3 (2004): 77.

4. Heidi Lee Hoerman, "Why Does Everybody Hate Cataloging?" Cataloging \& Classification Quarterly 34, no. 1/2 (2002): 31-41.

5. Penny M. Beile and Megan M. Adams, "Other Duties As Assigned: Emerging Trends in the Academic Library Job Market," College \& Research Libraries 61, no. 4 (July 2000): 336-47.

6. Wilder, Demographic Change in Academic Librarianship.

7. Janet Swan Hill, "What Else Do You Need to Know? Practical Skills for Catalogers and Managers," Cataloging \& Classification Quarterly 34, no. 1/2 (2002): 245-46.

8. Daniel N. Joudrey, "A New Look at U.S. Graduate Courses in Bibliographic Control," Cataloging \& Classification Quarterly 34, no. 1/2 (2002): 80; Sherry L. Vellucci, "Cataloging across the Curriculum: A Syndetic Structure for Teaching Cataloging," Cataloging \& Classification Quarterly 24, no. 1/2 (1997): 35-59.

9. Ingrid Hsieh-Yee, "Cataloging and Metadata Education: A Proposal for Preparing Cataloging Professionals of the 21st Century. A Response to Action Item 5.1 of the 'Bibliographic Control of Web Resources: A Library of Congress Action Plan," submitted to the ALCTS/ALISE Task Force, Final Report, Dec. 2002; Web Version, Apr. 2003. Accessed Jan. 18, 2005, www.loc.gov/catdir/bibcontrol/CatalogingandMetad ataEducation.pdf

10. Association of College and Research Libraries, Personnel Administrators and Staff Development Officers Discussion Group, Ad Hoc Task Force on Recruitment and Retention Issues, "Recruitment, Retention \& Restructuring: Human Resources in Academic Libraries: A White Paper," Final Draft, May 20, 2002. Accessed Jan. 18, 2005, www.ala.org/ala/ acrl/acrlpubs/whitepapers/whitepapersreports.htm (ACRL members only). 
11. Some of these projects include: Liz Bishoff and William A. Garrison, "Metadata, Cataloging, Digitization, and Retrieval: Who's Doing What to Whom: The Colorado Digitization Project Experience," paper presented at the Library of Congress Bicentennial Conference on Bibliographic Control for the New Millennium: Confronting the Challenges of Networked Resources and the Web, Nov. 2000. Accessed Jan. 18, 2005, http://cweb.loc.gov/catdir/bibcontrol/bishoff_paper.html; Kevin L. Butterfield, "Cataloger's [sic] and the Creation of Metadata Systems: A Collaborative Vision at the University of Michigan," OCLC Internet Cataloging Project Colloquium Position Paper. Accessed Jan. 18, 2005, http://webdoc.sub.gwdg.de/ebook/aw/ oclc/man/colloq/butter.htm; Char Simser and Mirian Childs, "Revolutionary Relationships: Catalogers' Liaison Role As Metadata Experts in the Creation of the K-State Digital Library," The Serials Librarian 44, no. 3-4 (2003): 223-28.

12. Robert Rodriguez, "Ten Tips for Cataloger Survival," Technical Services Quarterly 93, no. 3 (1992): 15.

13. Liz Bishoff, "Recruiting, What Next?" in Recruiting, Educating and Training Cataloging Librarians: Solving the Problems, ed. by Sheila S. Intner and Janet Swan-Hill, New Directions in Information Management, no. 19 (New York: Greenwood, 1989): 39-51.

14. As examples, see Peter Spyers-Duran, "The Effects of Automation on Organizational Change, Staffing, and Human Relations in Catalog Departments," in Requiem for the Card Catalog: Management Issues in Automated Cataloging, ed. by Daniel Gore, Joseph Kimbrough and Peter SpyersDuran, New Directions in Librarianship, no. 2 (Westport, Conn.: Greenwood Press, 1979): 29-39; Ruth Hafter, Academic Librarians and Cataloging Networks: Visibility, Quality Control, and Professional Status, Contributions in Librarianship and Information Science, no. 57 (New York: Greenwood, 1986); Sheila S. Intner, "What Is Your Catalog Worth?" Technicalities 16, no. 4 (Apr. 1996): 2-3; Mary M. Rider, "Developing New Roles for Paraprofessionals in Cataloging," Journal of Academic Librarianship 22, no. 1 (Jan. 1996): 26-32.

15. Deborah A. Mohr and Anita Schuneman, "Changing Roles: Original Cataloging by Paraprofessionals in ARL Libraries," Library Resources \& Technical Services 41, no. 3 (July 1997): 205-18.

16. Magda El-Sherbini and George Klim, "Changes in Technical Services and Their Effect on the Role of Catalogers and Staff Education: An Overview," Cataloging \& Classification Quarterly 24, no. 1/2 (1997): 25.

17. Janet Swan Hill, "Wanted: Good Catalogers," American Libraries 16 (Nov. 1985): 730.

18. "CCS Task Force on Education and Recruitment for Cataloging Report, June 1986," RTSD Newsletter 11, no. 7 (1986): 71-78.

19. Roma Harris, "Information Technology and the De-skilling of Librarians; or the Erosion of a Woman's Profession," Computers in Libraries 12, no. 1 (Jan. 1992): 8-15.

20. Hafter, Academic Librarians and Cataloging Networks, 63.

21. Janet Swan Hill, "Transcending Widgets: The Nature of Technical Services," Library Collections, Acquisitions \& Technical Services 27, no. 4 (Winter 2003): 377-91.
22. Marilyn Myers, "Who Does What in Acquisitions and Cataloging? Allocation of Duties between Professionals and Paraprofessionals in Library Technical Services: Report of the ALCTS Role of the Professional in Academic Research Technical Services Departments Discussion Group Meeting, American Library Association Midwinter Meeting, San Antonio, January 1996," Technical Services Quarterly 14, no. 2 (1996): 65-67.

23. Peggy Johnson, "Managing Changing Roles: Professional and Paraprofessional Staff in Libraries," Journal of Library Administration 22, no. 2/3 (1996): 79-99.

24. Mary Grenci, "Is Technical Services Being Deprofessionalized?: A Report of the ALCTS Role of the Professional in Academic Technical Services Discussion Group Meeting, American Library Association Annual Conference, Washington, D.C., June 1998," Technical Services Quarterly 17, no. 2 (1999): 55 .

25. Ibid., 52 .

26. Sheila S. Intner, "The Re-Professionalization of Cataloging," Technicalities 13, no. 5 (May 1993): 6.

27. Bishoff, "Recruiting, What Next?" 42.

28. Sheila Intner and Janet Swan Hill, eds., Recruiting, Educating, and Training Cataloging Librarians: Solving the Problems, New Directions in Information Management, no. 19 (New York: Greenwood, 1989).

29. Yuan Zhou, "Analysis of Trends in Demand for ComputerRelated Skills for Academic Librarians from 1974 to 1994," College \& Research Libraries 57, no. 3 (May 1996): 259-72.

30. Zahiruddin Khurshid, "The Impact of Information Technology on Job Requirements and Qualifications for Catalogers," Information Technology and Libraries 22, no. 1 (Mar. 2003): $18-21$.

31. Hong $\mathrm{Xu}$, "The Impact of Automation on Job Requirements and Qualifications for Catalogers and Reference Librarians in Academic Libraries," Library Resources \& Technical Services 40, no. 1 (Jan. 1996): 9-31.

32. David W. Reser and Anita P. Schuneman, "The Academic Library Job Market: A Content Analysis Comparing Public and Technical Services Positions," College \& Research Libraries 53, no. 1 (Jan. 1992): 49-59.

33. Beile and Adams, "Other Duties As Assigned."

34. Abdus Sattar Chaudhry and N. C. Komathi, "Requirements for Cataloging Positions in the Electronic Environment," Technical Services Quarterly 19, no. 1 (2001): 4-5.

35. David Burke, "From Catalogers to Ontologists: Changing Roles and Opportunities for Technical Services Librarians," The Serials Librarian 46, no. 3/4 (2004): 221-26.

36. Mihoko Hosoi, Cataloging Positions in U.S. Academic Libraries: An Analysis of Job Advertisements, 1999 (master's paper, School of Library and Information Science, University of North Carolina at Chapel Hill, July 2000). Accessed Jan. 18, 2005, http://ils.unc.edu/MSpapers/2621.pdf.

37. Lois Buttlar and Rajinder Garcha, "Catalogers in Academic Libraries: Their Evolving and Expanding Roles," College d Research Libraries 59, no. 4 (July 1998): 311-21.

38. Ibid.

39. Ibid.

40. Association for Library Collection \& Technical Services Continuing Education Task Force, "Continuing Education 
for Catalogers: Summary of Survey Responses,” Mar. 2003. Accessed Jan. 18, 2005, http://darkwing.uoregon.edu/ $\sim$ chixson/cetf/surveyresults.html

41. Mary Monson, "A Report of the Meeting of the ALCTS Role of the Professional in Academic Technical Services Discussion Group, American Library Association Annual Conference, Atlanta, June 2002," Technical Services Quarterly 21, no. 1 (2003): 64-68.

42. Christine DeZelar-Tiedman, “ALA Midwinter 2000: Conference Report: ALCTS Role of the Professional in Academic Technical Services Discussion Group," Library Collections, Acquisitions \& Technical Services 24, no. 4 (Winter 2000): 482-83.

43. Ibid.

44. Michael Wright, "Report on the ALCTS Role of the Professional in Academic Technical Services Discussion Group Meeting, American Library Association Midwinter Meeting, San Diego, January 2004," Technical Services Quarterly 22, no. 1 (2004): 61-68.

45. Rebecca L. Mugridge, "Report on the ALCTS Technical Services Directors of Large Research Libraries Discussion Group Meeting, American Library Association Midwinter Meeting, San Diego, January 2004," Technical Services Quarterly 22, no. 1 (2004): 75-76.

46. As examples, see Norm Medeiros, "Delivering the Goods: Web OPACs and the Expanding Role of the Cataloger," Issues in Science and Technology Librarianship, Spring 1998. Accessed Jan. 18, 2005, www.library.ucsb.edu/istl/98spring/article3.html. Norman Oder, "Cataloging the Net: Can We Do It?” Library Journal 125, no. 16 (Oct.1, 1998): 47-51; Norman Oder, "Cataloging the Net: Two Years Later," Library Journal 125, no. 16 (Oct. 1, 2000): 50-51.

47. Karen L. Horney, "Taking the Lead: Catalogers Can't be Wallflowers!" Technicalities 15, no. 5 (May 1995): 10.

48. Brian E. C. Schottlaender, "Why Metadata? Why Me? Why Now?" Cataloging and Classification Quarterly 36, no. 3/4 (2003): 19-29. Butterfield, "Cataloger's [sic] and the Creation of Metadata Systems"; Simser and Childs, "Revolutionary Relationships."

49. Gloriana St. Clair, "Preface: Chaos, Convenience, and Catalogers," Cataloging \& Classification Quarterly 30, no. 1 (2000): xix-xxiv.

50. Ingrid Hsieh-Yee, "Cataloging and Metadata Education in North American LIS Programs," Library Resources \& Technical Services 48, no. 1 (Jan. 2004): 59-68.

51. Patricia A. Eskoz, "The Catalog Librarian-Change or Status Quo? Results of a Survey of Academic Libraries," Library Resources \& Technical Services 34, no. 3 (July 1990): 380-92.

52. Wilder, "Demographic Trends Affecting Professional Technical Services Staffing."

53. Jane Padham Ouderkirk, "Staff Assignments and Workflow Distribution at the End of the 20th Century: Where We Were, Where We Are, and What We'll Need to Be," Cataloging \& Classification Quarterly 30, no. 2/3 (2000): 346.

54. Kathleen L. Wells, "Hard Times in Technical Services: How Do Academic Libraries Manage? A Survey," Technical Services Quarterly 21, no. 4 (2004): 25.

55. Ibid.
56. Ibid

57. Ibid

58. Ibid.

59. Ibid., 23.

60. Ibid.

61. "CCS Task Force on Education and Recruitment for Cataloging Report.”

62. Association of College \& Research Libraries, "Recruitment, Retention, and Restructuring," 14.

63. Wilder, "Demographic Trends Affecting Professional Technical Services Staffing," 53.

64. Hoerman, "Why Does Everybody Hate Cataloging."

65. Evan St. Lifer, "The Boomer Brain Drain: The Last of a Generation?" Library Journal 125, no. 8 (May 1, 2000): 40.

66. Association of College \& Research Libraries, "Recruitment, Retention, and Restructuring."

67. Norman Oder, "New Movement for Ph.D.'s to Work in Academic Libraries: Yale Symposium, CLIR Program Respond to Emerging Needs, Spur Debate About Bypassing LIS Education," Library Journal 128, no. 11 (June 15, 2003): $16-17$.

68. Buttlar and Garcha, "Catalogers in Academic Libraries," 315.

69. Ibid.

70. Eskoz, "The Catalog Librarian-Change or Status Quo?"

71. Kenneth Furuta, "The Impact of Automation on Professional Catalogers," Information Technology and Libraries 9, no. 3 (Sept. 1990): 242-52.

72. Buttlar and Garcha, "Catalogers in Academic Libraries."

73. Katherine A. Libby and Dana M. Caudle, "A Survey on the Outsourcing of Cataloging in Academic Libraries," College d Research Libraries 58, no. 6 (Nov. 1997): 550-60.

74. Buttlar and Garcha, "Catalogers in Academic Libraries."

75. For example, Michael Gorman, "The Corruption of Cataloging," Library Journal 120 (Sept. 15, 1995): 32-34.

76. Buttlar and Garcha, "Catalogers in Academic Libraries"; Hosoi, Cataloging Positions in U.S. Academic Libraries.

77. Monson, "A Report of the Meeting of the ALCTS Role of the Professional in Academic Technical Services Discussion Group, American Library Association Annual Conference, Atlanta, June 2002."

78. Mary Grenci, "Library Schools and Education of the Technical Services Professional: A Report of the ALCTS Role of the Professional in Academic Technical Services Discussion Group Meeting, American Library Association Midwinter Meeting, Philadelphia, January 1999," Technical Services Quarterly 17, no. 4 (2000): 65-67.

79. Beacher J. Wiggins, "Bibliographical Control of Web Resources: A Library of Congress Action Plan,” Dec. 20, 2001. Accessed Jan. 18, 2005, http://cweb.loc.gov/catdir/bibcontrol/actionplan.html

80. ALCTS Continuing Education Task Force (Action Item 5.3), "Cataloging for the 21st Century: A Proposal for Continuing Education for Cataloging Professionals: A Response to Action Item 5.3 of the "Bibliographic Control of Web Resources: A Library of Congress Action Plan," submitted to the ALCTS Advisory Task Force on the LC Action Plan for Bibliographic Control of Web Resources, Final Report, Aug. 8, 2003. Accessed Jan. 18, 2005, http://darkwing.uoregon. edu/ chixson/cetf/CETF_Final_Report.pdf 
81. Hsieh-Yee, "Cataloging and Metadata Education."

82. Brad Eden, "Report on the ALCTS Heads of Cataloging Departments Discussion Group, American Library Association Midwinter Conference, Philadelphia, January 2003," Technical Services Quarterly 21, no. 2 (2003): 76-79.
83. Hsieh-Yee, "Cataloging and Metadata Education in North American LIS Programs.”

\section{Appendix. Supply and Demand for MLS Catalogers Survey}

Instructions: Please answer the following questions concerning your library by circling the appropriate letter or filling in the answers as necessary. All information that you provide will be considered confidential. In the following questions, the term paraprofessional includes any individual that is employed in a cataloging position that does not require an MLS degree. Thank you for your participation in our survey. Please return your questionnaire by November 3, 2003.

\section{Demographics}

1. How many MLS and paraprofessional catalogers (FTE) does your library employ?

2. How many (FTE) of your library's catalogers have an MLS degree?

3. How many (FTE) of your library's catalogers are paraprofessionals?

4. How many (FTE) of your library's MLS catalogers are age 50 or older?

5 . How many (FTE) of your library's paraprofessional catalogers are age 50 or older?

6. How many (FTE) of your library's paraprofessional catalogers were hired specifically for their subject or language expertise (such as, music or Slavic languages)?

7. Does your library use library science practicum students or interns to do cataloging? $\quad$ a. Yes $\quad$ b. No

8. Since 1998, have the numbers of FTE MLS catalogers in your library ...

a. Decreased (continue on to questions 9-12, and then continue to question 18).

b. Increased (continue on to questions 13-17, and then continue to question 18).

c. Stayed the same (continue on to question 18).

9-12. If the numbers of MLS catalogers decreased, what do you think were the factors involved in that reduction?

9. Numbers of MLS catalogers decreased due to retirements or resignations
a. Yes
b. No c. Don't know

10. Numbers of MLS catalogers decreased due to less need for MLS cataloging skills
a. Yes
b. No c. Don't know

11. Numbers of MLS catalogers decreased due to position and/or funding reallocation to other areas of the library
a. Yes
b. No c. Don't know

12. Numbers of MLS catalogers decreased as fewer qualified candidates applied to fill vacant positions
a. Yes
b. No c. Don't know

13-17. If the numbers of MLS catalogers increased, what do you think were the factors involved in that increase?

13. MLS catalogers needed with knowledge of special languages, subjects and/or formats (such as, Slavic languages, music, electronic resources, maps).
a. Yes
b. No c. Don't know

14. MLS catalogers needed with more advanced knowedge of technological innovations in cataloging (for example, metadata experience)
a. Yes
b. No c. Don't know

15. MLS catalogers needed for supervisory/leadership skills/roles.
a. Yes
b. No
c. Don't know

16. MLS catalogers needed as trainers.
a. Yes
b. No
c. Don't know

17. MLS catalogers needed for special projects (for example, retrospective conversion, database clean-up).
a. Yes
b. No c. Don't know

18. Does your library currently have MLS cataloging vacancies?
a. Yes
b. No (continue on to question 20)
c. N/A (continue on to questions 20) 
19. If yes, have these vacant MLS cataloger positions not been advertised due to a reduction in the Library's budget? a. Yes b. No

20. Has your library lost MLS cataloging positions?

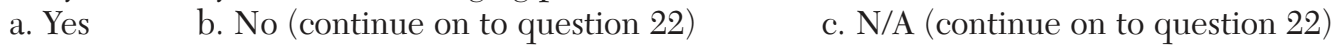

21. Were these positions lost due to a reduction in the library's budget?
a. Yes
b. No

\section{Recruitment of Catalogers}

22. When did your library hire its last MLS cataloger?
a. Within the last year
b. Two to four years
c. Five or more years

23. Since 1998, has your library had problems recruiting MLS catalogers?

a. Yes (continue on to questions 24-29, and then continue to question 30).b. No (continue on to question 30).

c. N/A (continue on to question 30).

24-27. There are a number of reasons why a library may have difficulty recruiting MLS catalogers. In your opinion, were the following factors part of the difficulty at your institution?

Circle your answer

24. Lack of qualified applicants yes no don't know

25. Criteria for tenure or continuing appointment yes no

26. Desirability of the community or institution's location yes no don't know

27. Lack of a competitive salary yes no don't know

28-29. Which of the above factors was the most significant and second most significant factor in your library's difficulty in recruiting MLS catalogers? Put number of item in the appropriate box.

Most significant

Second most significant

\section{Changing Cataloger Roles}

30. Since 1998, has the amount of time the MLS catalogers in your library spend on cataloging....

a. Decreased (continue on to questions 31-38, and then continue to question 46).

b. Increased (continue on to questions 39-45, and then continue to question 46).

c. Stayed the same (continue on to question 46).

31-36. If the time MLS catalogers spend on cataloging has decreased, in your opinion were the following conditions a factor in that reduction?

Circle your answer

31. More cataloging being done by paraprofessionals yes no don't know

32. MLS catalogers knowledge/experience needed for training yes no don't know

33. More time spent on library service (library committees) yes no don't know

34. More time spent on tenure requirements or continuing appointments yes no don't know

36. More time spent on cataloging related activities (systems integration, vendor product implementation) yes no don't know

37-38. Which of the above factors was the most significant and second most significant factor in the reduction of time MLS catalogers spent on cataloging. Put number of item in the appropriate box.

Most significant

Second most significant

39-43. If the time MLS catalogers spend on cataloging has increased, in your opinion were the following conditions a factor in the increase?

Circle your answer

39. More items to be cataloged yes no don't know

40. Fewer total catalogers to do the work yes no don't know

41. More materials lack established cataloging guidelines yes no don't know

42. Priorities changed by administration yes no don't know

43. Improved access desired (subject headings, classification numbers) yes no don’t know 
44-45. Which of the above factors was the most significant and second most significant factor in the increase of time MLS catalogers spent on cataloging. Put number of item in the appropriate box.

Most significant

Second most significant

46. In light of the changing nature of cataloging, how strongly do you feel your library has encouraged the continuing education/training of MLS catalogers?
a. No encouragement
b. A little
c. Medium
d. Strongly encourages e. Don't know

47. How often does your library use vendor-based products to assist with cataloging (such as outsourcing, PromptCat, Serials Solutions)?
a. Never
b. Sometimes
c. Often
d. Don't know

If never or don't know, continue on to question 49.

48. If seldom, sometimes, or often, was the decision to use vendor-based products due to:

a. Lack of qualified MLS or support staff catalogers to do the cataloging

b. Library budgetary issues

c. Both lack of catalogers and budgetary issues

d. Other, please specify:

49. Has your library made any effort to showcase and explain the knowledge, skills and roles of MLS catalogers to other areas of the library and university community? a. Yes b. No

If yes, please elaborate on what your institution has done.

50. Would you recommend someone consider an MLS degree in cataloging? a. Yes b. No

\section{Future State of Cataloging/Catalogers}

The following are several different scenarios for the future of MLS catalogers in the library profession as a whole. Please respond if you strongly disagree, disagree, agree, or strongly agree to the following statements.

51. Libraries will recruit for beginning level MLS cataloger positions
a. Strongly disagree
b. Disagree
c. Agree
d. Strongly agree
e. No opinion

52. MLS cataloger responsibilities will shift from cataloging to more administration and management tasks.
a. Strongly disagree
b. Disagree
c. Agree
d. Strongly agree
e. No opinion

53. MLS cataloger responsibilities will shift from cataloging to more training tasks.
a. Strongly disagree
b. Disagree
c. Agree
d. Strongly agree
e. No opinion

54. Libraries will hire graduates with subject and/or language degrees and train them in cataloging skills and knowledge.
a. Strongly disagree
b. Disagree
c. Agree
d. Strongly agree
e. No opinion

55. Libraries will rely more on outsourcing their cataloging materials.
a. Strongly disagree
b. Disagree
c. Agree
d. Strongly agree
e. No opinion

56. This survey has covered many issues that may affect catalogers and cataloging in the future, such as changing numbers and roles of catalogers and the time devoted to cataloging. Overall, do you feel your institution is prepared for these issues?
a. Very unprepared
b. Unprepared
c. Prepared d. Very prepared
e. No opinion

57 . Briefly explain your answer to question 56 , giving examples, if possible.

In the following space, please feel free to expand your answers to any of the above questions or comment on the recruitment of catalogers, adjusting or changing workflows specific to cataloging or the future of cataloging in general. Thank you for taking the time to answer our survey and participate in our research. 